\title{
Maintaining Pakistani Cultural Traditional Decorative Elements Blending and Adoption Different Decorating Style Approach
}

\author{
Romana Yasmin khan $^{1}$, Kangli Ren ${ }^{1}$, Wei Gan ${ }^{1}$, Zain ul Wahab ${ }^{1}$ \\ ${ }^{1}$ School of Architecture and Urban Planning, Huazhong University of Science and Technology, Wuhan, China \\ Correspondence: Jianjun Huang, PHD in Art and Design, School of Architecture and Urban Planning, Huazhong \\ university of Science and Technology, Wuhan, China.
}

Received: February 6, 2019

doi:10.11114/ijsss.v7i3.4138
Accepted: March 12, $2019 \quad$ Available online: March 13, 2019

URL: https://doi.org/10.11114/ijsss.v7i3.4138

\begin{abstract}
Pakistani culture has the capacity to adopt multi-cultural values and décor practices in the society. With the gradual improvement of the living environment, people are pursuing more satisfaction and spiritual meaning the current interior decoration style in Pakistan considers a mix and match style. People in Pakistan cannot absolutely consider adopting a pure one style. Interior decoration is considered as primary to traditional living culture with distinctive cultural ideas, filling in the use of the latest style of thinking. The purpose of this study is to explore the development and current status of interior decoration styles in modern Pakistan and to collect background information on the current interior design decoration style and application of traditional elements in decoration.

Also, investigate the extent of application of traditional thoughts in modern houses, their incorporation and blend with contemporary architecture so that the cultural values and the elements of traditional interior décor art and craft are not endangered. Study reveals that Pakistani interior décor style is the foremost interesting and attention-grabbing to work with because of the variations within the culture, splendid history and art and craft across the country.
\end{abstract}

Keywords: traditional craft culture, interior design, decorative elements, décor style factors

\section{Introduction}

Style considered as adopted concepts and ideas and exists in a various fields. According to (Chen and Owen, 1997) definition of style differ throughout many aspects like linguistics, musicology, literature, elements of visual art and architecture etc. To describe a national identity in interior decoration style isn't an easy task because of many factors, particularly if it's a nation created from several cultural class, with many various manners, practice and traditions and with no doubt influence of history. In Pakistan there are five provinces and home of various civilizations and back ground of splendid art history, these powerful factors that have an effect on cultural characteristics and identity, and that cause of its modification and substitution, and these factors differ from one to another.

The culture of a state contains several aspects. Various factors involve forming by the background of its individuals, such as families belong from an area and beliefs. The social scientist (Hall, 1959) defined culture that the Culture is not like an unusual or strange concept studied by a certain group of anthropologists, it is a form that controls in our lives in which we are cast. Cultural application in modern society particularly the meaningful creation of style, embody the cultural, traditional and religious values that provides personally and collectively identity. Pakistanis would ignore their cultural art and style if relying only on the international manufacture products and adopt totally different international interior decor style that can make confusion within the identity of a country. There's no fault in receiving international styles and trends, as (Castells, 2010) said that our lives and a world are being notion by the contrast or a different style of globalization and identification of individual. However, there should be balance, by providing a new blending design concepts and prosperous alternative of the traditional vogue to match needs of the individuals and with the same time flourish decorative décor art with the world market. An elaborated study of the Pakistani traditional style can be helpful to determine fundamental decorating style characteristics from that to get new concepts also with mix and match styles that sustain the Pakistani traditional interior decoration identity. It is seen commonly decorative elements available in interior designs used by the people in history. It is a common observation that Pakistani traditional design components are strongly enriched with an esthetic value that contains beauty of traditional culture. Pakistani artifacts have the strengths not to be ignored upon having good experience faced by the people. That is why it is having a long historical linkage with 
interior decoration.

This study came from the requirement to search out the current furnishings or decor homes trend within the cultural values and heritage identity, Pakistani people adopting different style and what causes behind? Ever confusing what trends in interior decorative style are most famous in Pakistan? Will try to find this descriptive style in this study that not only obliging but also fun. There is no doubt that the traditional art are a very important source of innovation once creating new ideas, however what if the method of generation ends up in platitude designs? The main focus of this study involves of a use of traditional elements for interior ornamentation in modern living and which decorative style people adopt to fulfil the requirement of modern livings with in the cultural values. In past few years, a sort of recognition has been developed within which the individual as a full is dampened into a progression of cultural identifiers like history, location, gender, status, language, cultural vogue ,religions, aesthetics, beliefs, values, and so on. The goal of this study is to analyze as inspiration of making new ideas in décor blending or contribute with traditional characteristics and maintaining cultural vogue in trendy living without losing identity. The essence of traditional components into trendy interior décor each Combined with the different class or standards of style satisfy necessities of modern life and aesthetic needs.

Interior style ornament has several variants, once describe the most recent build house and interior designing trends in Pakistan, one might not outline clearly because the houses constructed in classy housing societies or developed housing society are completely different from those which made in less posh areas.

\section{Methodology}

This study conducted through literature, observations, interview with common people, architects and designers was like having a conversation or discussion based on questions to evaluate style attitudes, beliefs, opinions, and characteristics of Pakistani people.

\section{Pakistani Traditional Decorative Art Style Development and Changes in the Historical Process}

Pakistan's traditional decorative art can be traced by history. The existence of splendid history is a significant part in the long-term process of advancement and evolution thus established excellent artistic characteristics. In addition, shape the local characters of Pakistani successor, and also drive the culture and decorative art forward with its exclusive exquisite concepts. The transferal of Pakistani cultural transformation across time and space is not consider a new phenomenon.it is occur due to migration of people, political and economic power, and influence of individual thoughts, theses all components have a distribution of culture. But some time geographical and political boundaries make cultural dispersion slow and limited. At the same time it cannot be ignored that the characteristics of traditional cultural style are mixture the sub-continent culture. This mixture makes the Pakistani culture a strong and rich culture for the people. This richness can be seen in various aspects of the design such as visual arts including painting, architecture, textiles, decorative arts, and sculptures. Pakistani people who are not well familiar with the Pakistani designs consider it new and innovative / modern designs in the Western part of the world.

The architectural and interior decorative advancement can be seen by looking at the ancient artifacts of "Moen-Jo-Daro" and "Gandhara civilization". The first stage of the Pakistani history of carve stone sculptures and rock painting links back 2000 years old Mohenjo - Daro and Harappa civilization, which were used to make carve sculptures with stones and bronze and also were able to use various mediums for the picture depiction (Naqvi, 2010; Rao, 1973) Pakistan consider the center of old civilizations Gandhara as disclose by the ruins of Julian,Sirkhup, Sirsik and Gandhara which traced back up to 5000 BC (Dales,1964). They made small and huge sculptures of Buddha and other animals from available stones and constructed or carved them in mountains and other places of their worship (Wright, 2010). Director-General of Archaeology and Museums of Pakistan conference was sponsored by UNESCO, well said ( Naqvi,1973) "we are not preserving Moenjodaro as a luxury of archaeology; we are maintaining it because it is the art heritage of mankind. Mohenjo-Daro Conference (Naqvi, 1973) Pakistani traditional culture is backed up by the strong cultural heritage and is evolved formed and developed gradually thus giving rich traditional cultural warmth and comfort. Thus the values, lifestyles, ways of thinking, emotional form, and psychological characteristics are found in this culture. The same is observed in the social development of the societies up to great extent. By connoting a strong cultural heritage it targets multi-level thought, morality, customs, psychology, literature, art, system, and material and spiritual cultures.

However, there were two main states emerged controlled by Arab rule that was al- Mansurah and now that city of Multan. The Ghaznarid sultans gained leadership in 11 centers in Punjab. The succeeding control of the Moghuls, they raised in central Asia, who lasted from 1536 to 1707; their rule remained until 1857. They built and established a sophisticated administration and involved in great deal of art and culture and they left a rich heritage of architecture like, forts and walled cities, mosques, tombs and gardens and gateways. (The common wealth, History of Pakistan)

The marks of the Islamic Mughal era are the standing evidence for the strong cultural heritage of Pakistan and can be 
traced in architecture, painting, metal work and other Islamic decorative art. Most of the Islamic art of, whether consists of architecture, literature, textile, ceramic and others elements, is the art of ornamentation - so called, of transformation The Evolution of Style (David Wade, 2006) Due to the spread artifacts of the ancient civilizations and glorious Islamic Mughal history design preferences a wide range of trends in designing can be observed in different parts of Pakistan in modern time which are given in Figure 1:

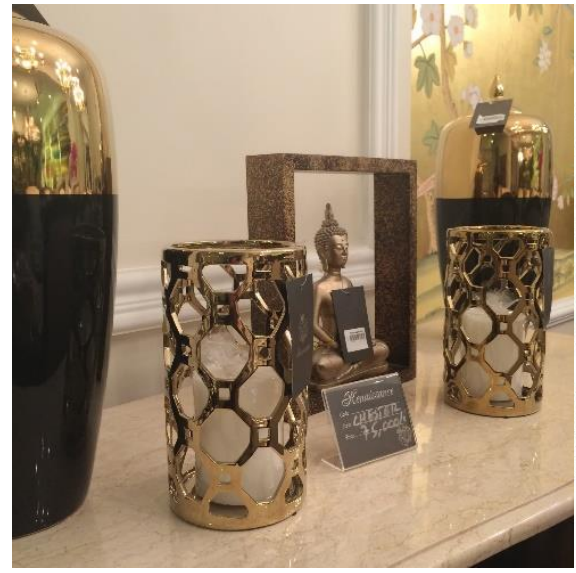

(a)

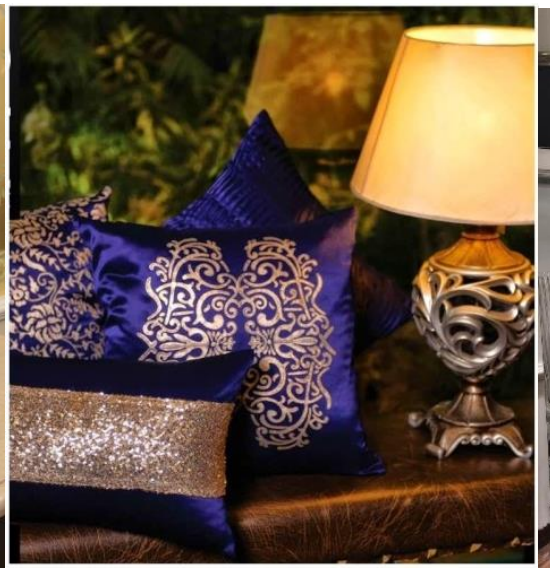

(b)

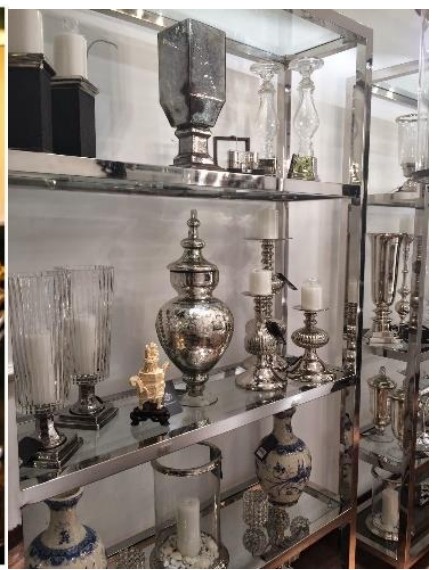

(c)

Figure 1

(a). Pakistani Contemporary and classic decorative accessories Buddha sculpture in decor store

(b). silk Mughal style cushion with floral patterns

(c). contemporary Islamic metal work silver accessories (Source: Karachista)

European traders arrived and occupied the subcontinent in the early 17th century. After Britain opposed the unsuccessful uprising in 1857, the British controlled it directly. A nationwide Muslim identity slowly emerged. (The common wealth)

For the first time during the British colonial age the buildings designed on Indo-European style were developed. The interior ornamentation of these buildings was sophisticated combination of European and Indo-Islamic components. Few examples of the architecture designs based on Indo-European can be seen in the form of Mohatta Palace and Frere Hall in one of the biggest cities of Pakistan known as Karachi. Moreover Craftsmanship is found in British furniture typically characteristics forms and pared down, elaborate stylized motifs suggestive of medieval, Islamic design (www.invaluable.com)

The "western and European influence is a phenomenon, western and European influence with traditional style will sustain the interior design industry in Pakistan especially in the context of developed housing societies. Actually many concepts and thoughts are well united into a typical traditional decorative style and no longer considered normally 'westernized. Pakistani Society is consistently regarding to preserving the traditional decorative style, while grabbing western interior design concepts with equal intensity that means diverse range of ideas to create a quite unique style in a broad way. Pakistan's furniture design is a combination of eastern and western style, due to the shared history with British. There are historical traditional values connected to the furniture all other decorative items in Pakistani society.

Contemporary Pakistani house styles mostly decorate with highly decorated objects two styles commonly using Baroque style and Victorian style. . The geographical origin of the Victorian style was England that began in 1830. By the end of 1900, the materials used were walnuts, mahogany, mahogany, and velvet. During the industrial revolution, furniture manufacturers and designers could promote or support the growing middle class furniture. Although in this era it involves many styles including handicrafts, Victorian furniture contains a large and sophisticated design. (Invaluable)

Baroque interior design consists of high-style lavish furnishing and interior decorating style which lasted from the early 17th to the mid-18th century. (Wikipedia) Baroque Furniture style can be identified by its highly ornate and luxurious lavish look. Complicated, exaggerated ornamentation having characteristics that often include flowers, leaves, and others different cherubs. Historically development in decorative art summarized in Table 1. 
Table 1. historical process of decorative Art

\begin{tabular}{ll}
\hline Historical periods & Decorative Elements \\
\hline Indus civilization artifacts & Bronze art ,carved stone sculptures \\
Gandhara civilization artifacts & Stone carving objects utensils and other decorative art, carved sculptures \\
Mughal Muslim period & Miniature painting, decorative geometric and arabesque pattern, carve wooden balconies, \\
& takhat(dewan), gardens fountains, precious stone inlay work, glazed pottery and tiles. metal \\
& work, mural art, calligraphy, carpets and rugs brocade velvet draperies and upholstery \\
British period furniture & Victorian style furniture, chest, davenport desk, laps chairs. Carved molded sofas and \\
& sections chairs, military raj chest \\
\hline
\end{tabular}

\section{Decorative Art Elements}

Culture includes explicit and implicit patterns, as well as patterns of behavior acquired and transmitted through symbols, constituting the unique achievements of the human population, including its manifestations in the cultural relics; the core of culture is traditional (historical derivative and selection) thinking and attached value (Kroeber \& Kluckhohn, 1952 and cited by Adler 1997)

The traditional culture of Pakistan has seen a gradual change in the culture of art and craft, contributions of skilled artisans are the prominent developments in the culture thus gradually forming unique personality that promotes prosperity and contributes in further development of Pakistan's culture

Pakistan's traditional decorative culture encourages variety of colours, patterns, textures in the indoor environment and these elements resemble the influences of nature. It is noted that "harmony between man and natural material " combines the environment of traditional living more comfortable such as natural material wood, clay, stones, jute etc.

Frequently observed traditional ingredients are engraved patterns. The availability of the decorated window and carved doors, carved furniture with inlay work are the most famous handicraft in Pakistani art. however the others decorative art such as embroidered wall hangings, enlightened painting, sophisticated calligraphy, textile printing and dyeing, embroidery, glazed painted pottery and porcelain work with ornamental floral patterns, brass /silver/bronze ornamental work, brass crafted vases with bidri nikashi and handmade carpets and rugs are consider Pakistani most famous craft. Traditional decorative art and craft elements shown in Figure 2.

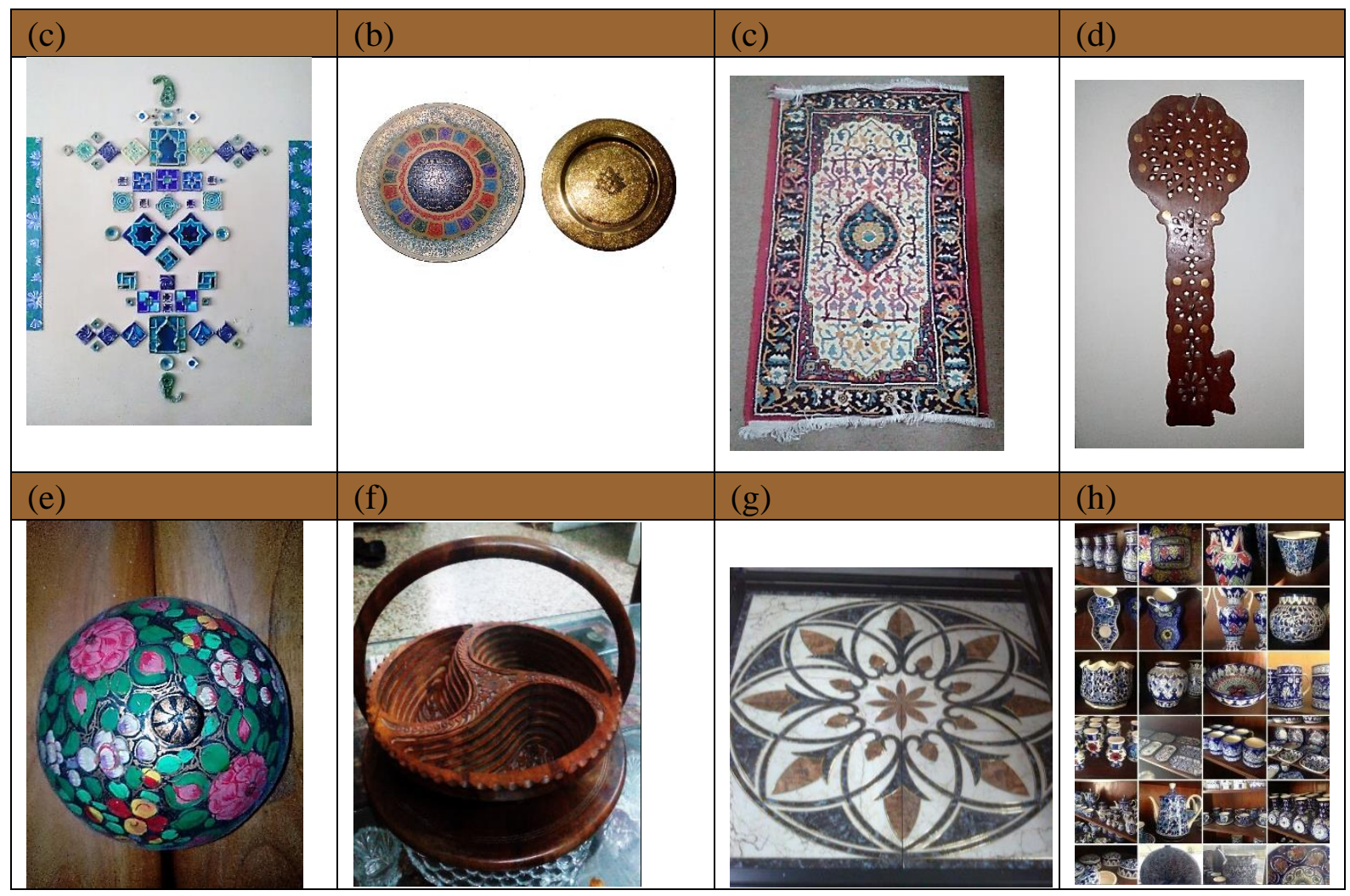




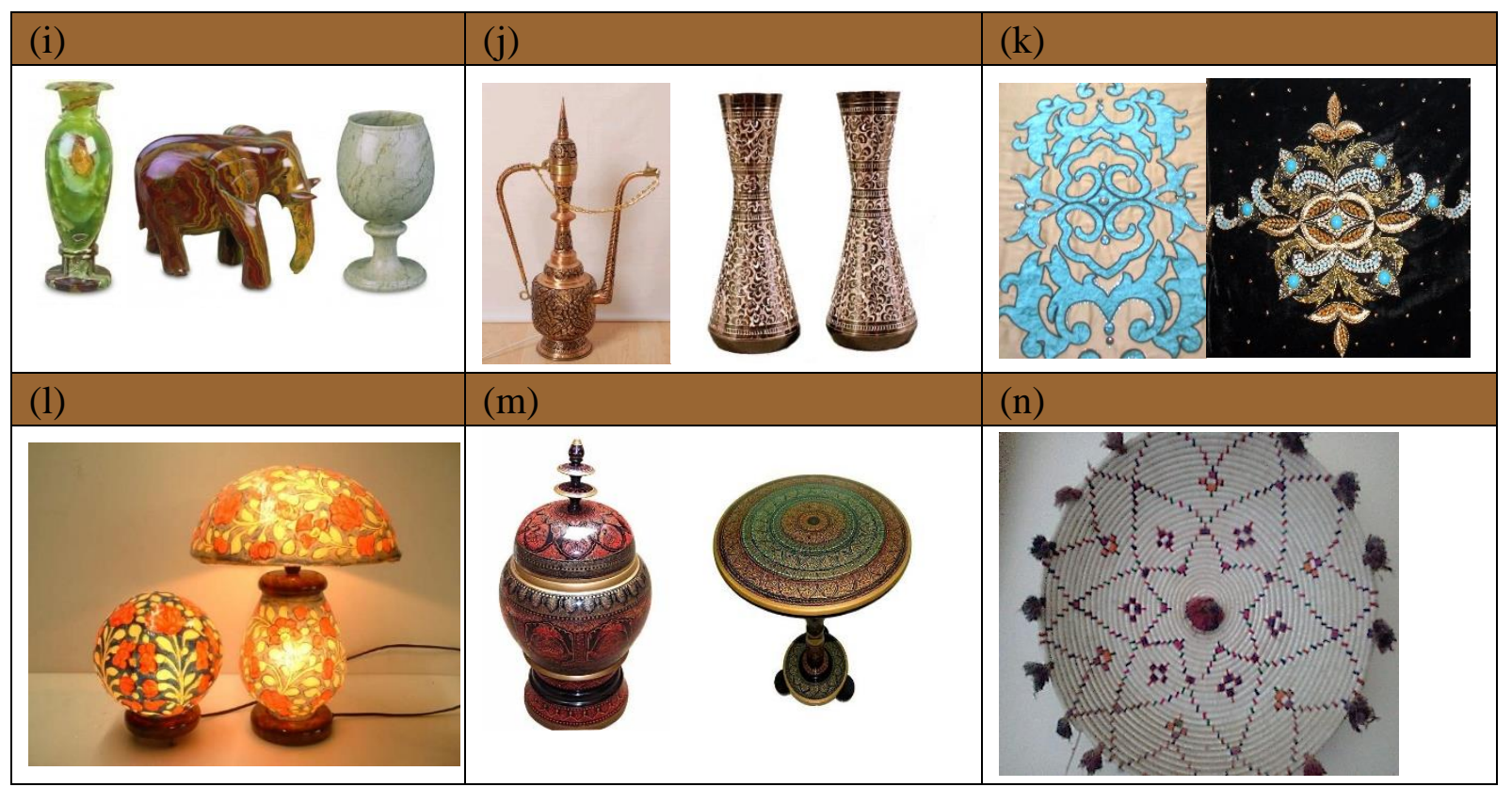

Figure 2. T Elements of Traditional decorative art and craft

(a) glazed tiles (b) engraved floral patterns with Islamic calligraphy metal decorative art (c) handmade rugs (d) brass inlay work(e) mache work (f) wood carving (g) marble work with brass art (h) glazed painted pot (i) onyx art work (j) brass engraved inlay vases(source:houseofpakistan) (k) salma sitara work (l) camel skin lamps art (houseofpakistan) (m) laquer art work (n) basketry chabi art

Handicraft is a part of Pakistani enriched culture thus counting towards distinctive Pakistani handy-crafts attraction. See below Table: 2

Moreover, few characteristics of the Pakistani traditional home décor culture can be seen for instance combination of traditional decorative products gives natural environment in house that highlights the natural feelings, interest, natural beauty and other distinctive features. Secondly, in the traditional environment decorative elements made of natural materials offers healthy living, enrich the interior decorative space with comfort environment by using a selection of particular variety of natural elements of design.

In addition, the decorative art style also has a long history having variety of features that are borrowed from the decorative elements of other countries of the world in past few decades. The manifested effects of decorative interior design show deep traditional cultural flavor and makes Pakistan an exclusive cultural repository. Pakistani decorative style in interior design is assuming the combination of ancient, Islamic traditional, European classic and contemporary elements.

Table 2. famous art work production provinces and cities in pakistan

\begin{tabular}{cc}
\hline Decorative Art & Province/cities \\
\hline Embroidery & Baluchistan /Sindh/kpk/Punjab/Gilgatbultistan \\
Carpets /rugs & Baluchistan /Sindh/kpk/Punjab/Gilgitbultistan \\
Carve wooden accessories & Punjab/kpk /Sindh \\
Metal /brass work & Kpk,Peshawar/Sindh Karachi/Punjab Lahore \\
Stone work & Punjab /Taxila \\
Glazed pottery & Sindh/Punjab \\
Glazed handmade Tiles & Sindh/Punjab \\
Painted lacquer/inlay work & Punjab/kpk/Sindh \\
Painting art & Punjab/Sindh/kpk \\
Onyx/marble inlay and carving art & Baluchistan / \\
\hline
\end{tabular}

Pakistani contemporary furniture style somehow had several mixing style such as heavy carved and highly elaborate Victorian style furniture with dark finishes mixing with Mughal style with heavy silk cushions and brocade and velvet upholstery. Figure 3 


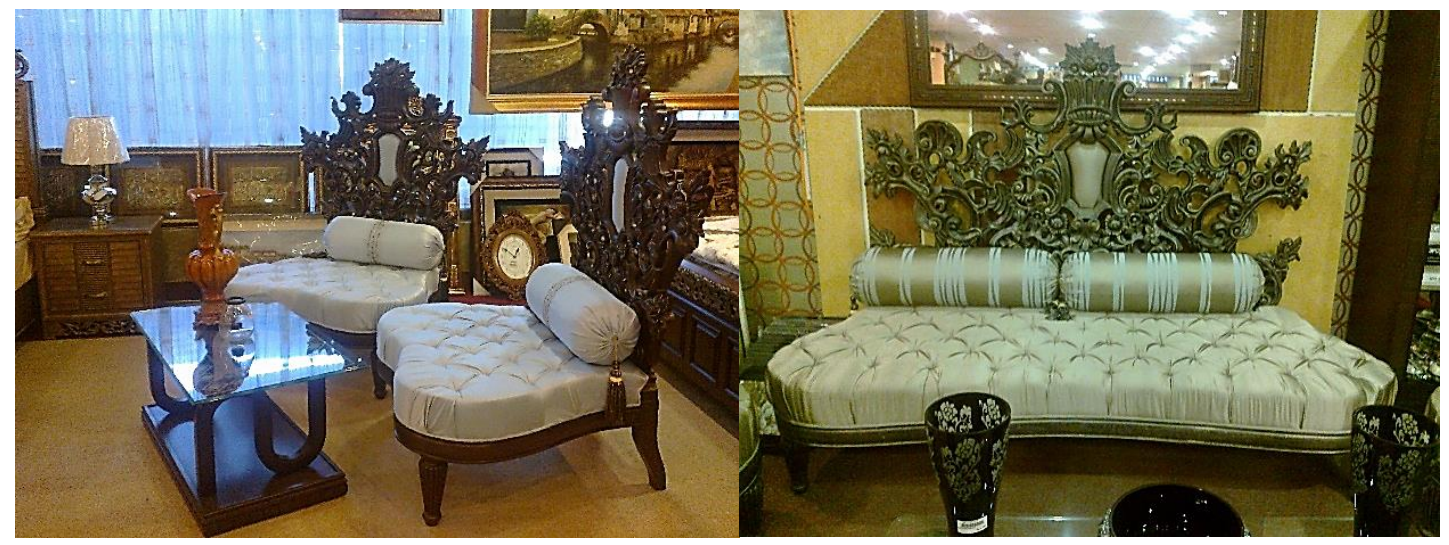

(a)

(b)

Figure 3. Victorian style dark finished, elaborate wood carving, combination of Islamic Mughal style like low seat divan and throne with brocade upholstery and cylindrical elongated cushions depicting Islamic Mughal style

These elements are enriched with solemnest and gracefulness. These include the characteristics of the Pakistani interior in house having engraved patterns or designs, carved furniture, and other characteristics stated above. This is liked and lived by the people living in their houses and enlightens the spark of life in human beings. Furthermore, the people are focusing on the transmission of the visual effects retrieved from the traditional and modern combinations and they have controlled to get the things accomplished well in contrast and matching colors. Figure 4

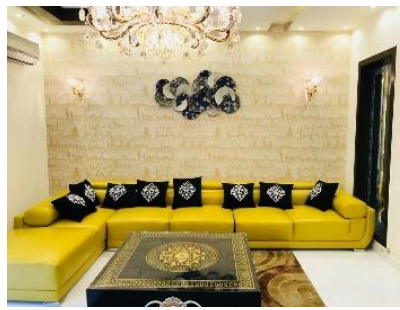

(a)

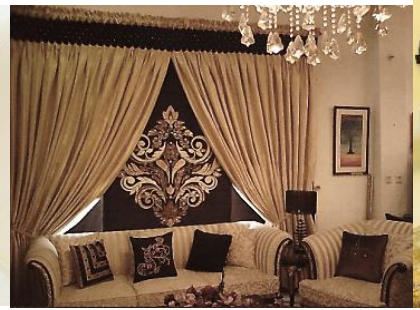

(b)

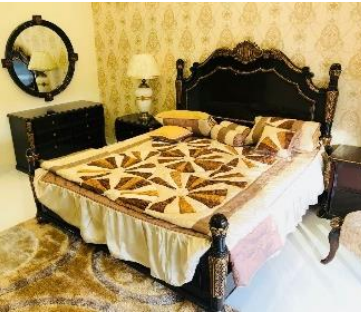

(c)

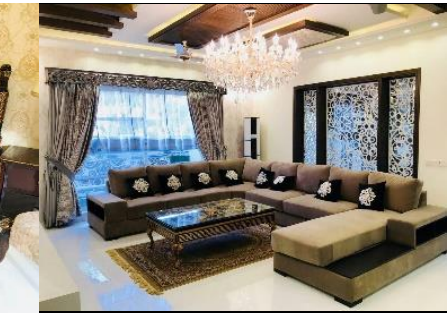

(d)

Figure 4. velvet and borocade cushions, handmade rug in (d), dreperies and upholsrty gold and silver Salma sitara work with diamatics stones

\section{Factors Influence on Pakistani Interior Design and Decoration}

As Chan, defines the factors of changing style that the constant application of certain component in a design process to develop common characteristics results style. The term features covers many detail treatments, different elements such as textures and colours, materials and its features (Chan, 2000). Hence, any genuine features to be appreciated if stylistic have these following properties. Pakistani decorative art style is not rigid; development of urbanization and improvement of Pakistani individuals living environment, people more concern about the entertainment and inner satisfaction. As matsumoto describes that attitudes, values, beliefs, and behaviors shared and link by a group of individuals but this set of attitude ,belief and behavior are different for each individual, transfer from one generation to the next generation " (Matsumoto, 1996). Hence, Pakistan's traditional decorative elements shaped in such a way which enriches Pakistanis modern living space, which bring extensive neo Pakistani style feeling and characteristics, that fulfilling individuals' needs to maintain traditional aesthetic values in modern living. Traditional style in decoration considered the most famous styles of interior decoration even today in modern life style, Pakistani traditional décor style has a European influence. Overwhelmed with rich dark colors and regal furniture, it is everything that speaks of class. Most traditional designs also use ornate and architectural elements to complete the look. Symmetry and balance are considered the two key parameters for the Pakistani traditional décor style of decorating homes. All the pieces of furniture are put in an ordered to maintain an important focal point. Moreover, the traditional tactics used such as using the space and surface of the room with paintings, wall hangings, glazed pottery items, brass (petal) work with contemporary style and carved items inlaid with a variety of patterns and other practices, so that the whole interior space gives a comfortable visual outcome, and understood expression of Pakistanis emotions and taste. 


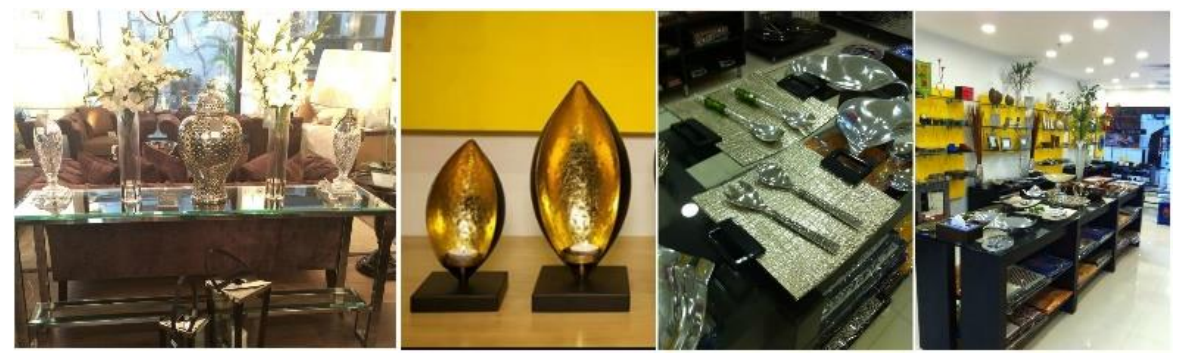

Figure 5. Imported decorative objects in home décor store Pakistan (source: dawn)

\subsection{Media Influence}

Through survey based on interviews and observation has noticed that Pakistani individuals starts begin picking out their favorite items within the available resources like interior design images from net or magazine or from any TV dramas serials (drama series like tele film serials which very popular in Pakistan). Mostly women watch and get inspiration from it weather in fashion cloths or interior design such as furniture articles, lamps, wall covering, window treatment or anything similar else that they wish to place in existing interior space in home .once they picked their favorites decorative ideas, thus start shopping and searching for selected or similar items in showrooms, handicraft shops and decorative local or imported accessories item shops. Pakistani interior design and décor style is somehow an eclectic style in which use variety in the interior decoration. Somehow, Pakistani interior decoration style is that put together in home follow the different time period, several styles in furniture items and accessories combine or blend together. Some extend Pakistani decorative interior style is great to use with a limited budget, because of have many design options, variety of style and products availability to incorporate them all at once in interior space .fig:6

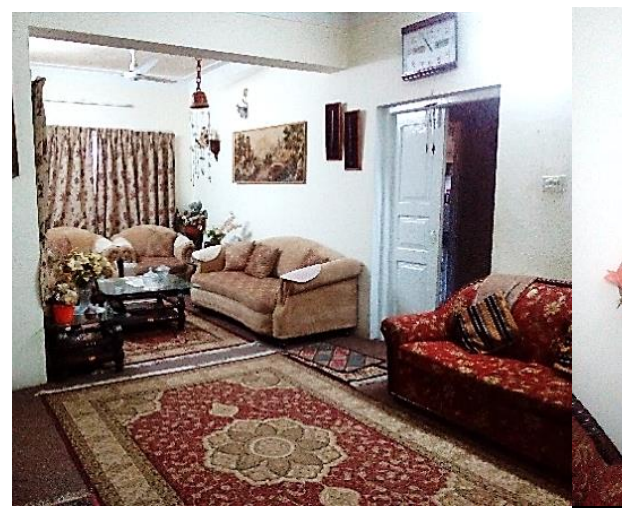

(a)

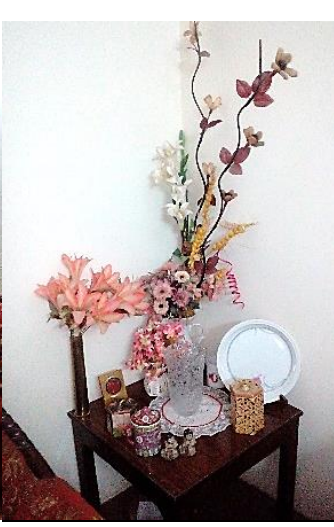

(b)

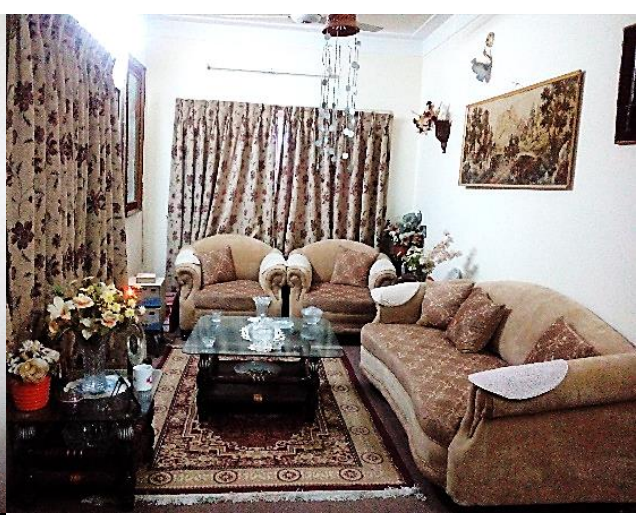

(c)

Figure 6. vareity of ornamenetal objects antique brass (peetal)vase and wall hanging ,islamic traditional glazed painted decorative vase and plates and handmade pakistani traditional carpets and rugs

Think of Pakistani interior decoration style as a borrowing of many styles, well-integrated and sometime unified look carefully through decorative elements like color, shape, and texture that all elements work together. But some time makes messy and cluttered when use too much heavy furniture, colours, textures and accessories in a room. Style can be develop by adding, reducing and change the rules (Knight, 1986). Looking at the aesthetic laws of traditional beauty includes the features like symmetry, balance, orderliness; harmony, contrast, and rhythm are the foremost. However, the formal beauty of Pakistani traditional decorative home is based on the three major principles such as symmetry, balance, and harmony. By considering symmetry as an element of beauty the decorative patterns in elements are seen simple, practical, and controllable. This provides grounds to using proper ratio that inculcates the aesthetic culture. Further the harmony shows a sense of wholeness that is valued by the people living in Pakistan.

\subsection{Family Bounds}

Interior design and decoration is the important factor for the residents to reside a happy life main thing that observed is Family bonds and association are very strong in Pakistani culture. Family comes first consider in Pakistani culture because of religious, cultural, and social values. Pakistani society is not considered as individualism, but rather collectivism thus their relationships are stand strongly supported by each other. Family views, suggestions have value while decorating a house. 


\subsection{Showcasing Prosperity}

Furthermore, new technology use in Pakistani construction and interior design that are adopted in a greatest extend in the recently launched housing societies in different cities of all provinces. It additionally depends on individual budget keeping in mind as Pakistan is expensive towards hire designer or decorator, buying branded article of furniture and interior decorative materials. New developed Pakistani housing societies and industrial revolution development transformed the living standard of middle class families specially those who came in the field of real estates and builders that make them more prosperous. Hence, for showcasing of their wealth Victorian and baroque style furniture with overly ornamented and highly detailed use with Mughal influence are more common .furthermore use of heavy draperies and upholstery became the priority style of furniture in order to fulfill the interior decorating requirements of the newly prosperous living. Fig: 7
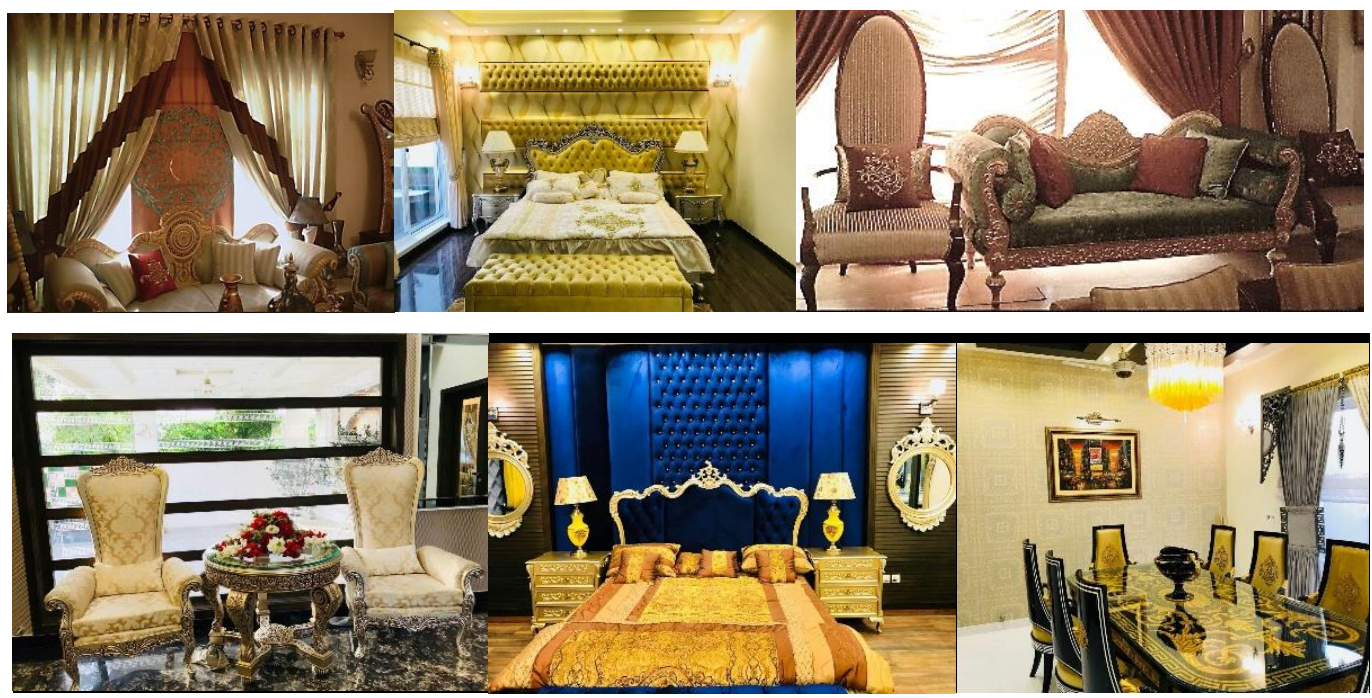

Figure 7. Heavy Victorian style and gilded furniture with highly elaborate draperies and upholstery with traditional bed sheets prints and silver and golden salma sitara motifs on cushions and Pakistani traditional brass (petal) work in table lamps

\subsection{Culture Exchange}

Many Pakistani families and students settled abroad for occupations, business and study such as UAE, England, Canada, America, Australia, china Malaysia, Saudi Arabia, and Europe etc. Studying and living in different countries and within an unfamiliar culture offer a great exposure and experience to Pakistanis. Thus Cultural exchange often provides them new environment in which they acquire adapting and learning a new things. When they come back they also brought new thoughts thus they tried to blend with Pakistani traditional local environment which greatly influence on living then the new style generate.

Culture can be viewed as an organized activity that is learned or created by community members. It can contain experiences; images based from previous generations, learn from social groups, or may originate from individuals themselves (Zegarac, 2007).

Furthermore, often Pakistani architects designer get a chance to attend workshops, and conferences abroad they also put effort to blend different style in Pakistani architecture, interior design and decoration. An individual's level of experience and exposure towards foreign lifestyles influence their taste, decisions and preferences. This attitude might be negative, positive and neutral. Figure 8 


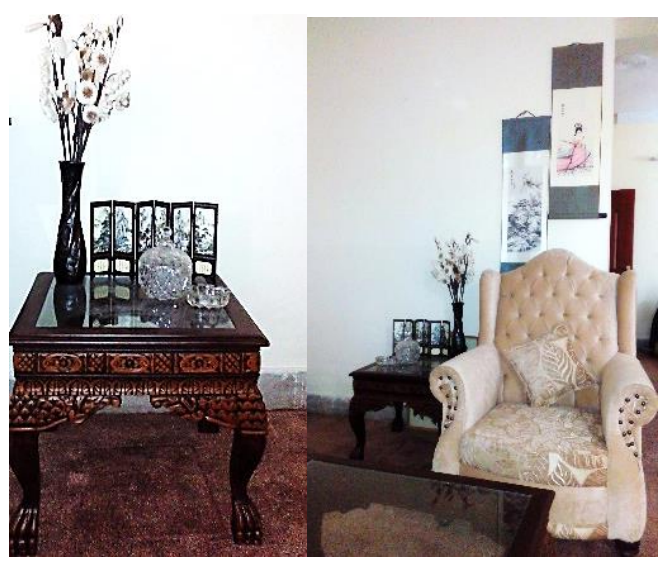

Figure 8. chines wall hanging and decoration accessories on traditional carve wooden table, chines influence in decoration

\subsection{Housing Societies}

Interior style and decoration concepts in Pakistan are typically dependent upon the approach individuals house are designed and what area of Pakistan individuals have a tendency to live in. Pakistani architecture reflects the cultural variety and distinction in style the country has intimate with through the ages. The past is represent in the wide span of architectural structure and in decorative style that utilize a distinctive mix of creative inspiration, material, layouts design, workmanship and construction. Details of Pakistani house style given in Table 3.

Table 3. Here is the detail of house styles in Pakistan:

\begin{tabular}{|c|c|}
\hline Types of houses & Features \\
\hline Big houses & with larger porch ,veranda ,lawn, terraces double story \\
\hline Small houses & $\begin{array}{l}\text { Constructed in a way to give a spacious. Unnecessarily stuffed } \\
\text { It also have double story }\end{array}$ \\
\hline $\begin{array}{l}\text { Airy and Ventilated } \\
\text { Houses } \\
\text { Smarter Homes }\end{array}$ & $\begin{array}{l}\text { (Smaller or larger) airy and brighter look. Larger size windows that much like mirrored doors having the } \\
\text { same or even more length and width. Make rooms and living room brighter and spacious double story houses } \\
\text { (Smaller or large )Using the latest and the smarter construction equipment, that are resistant to heat and cold. } \\
\text { to make a house more energy efficient install different kind of insulations, double story }\end{array}$ \\
\hline Simple houses & $\begin{array}{l}\text { less use of latest technology, traditional methods use } \\
\text { double story }\end{array}$ \\
\hline $\begin{array}{l}\text { Apartments or } \\
\text { studios apartments }\end{array}$ & $\begin{array}{l}\text { Simpler and less-space occupy interior objects like bed sofas and chairs .maximum comfort and get easily } \\
\text { adjust in a smaller area. }\end{array}$ \\
\hline Farm houses & Luxuries houses of Elite class ,politicians ,army officers , bureaucrats for entertainment \\
\hline
\end{tabular}

Furthermore, planning interior of a house depends a lot of on the budget homeowner has. Through survey in housing societies, made interview with architects whom associate with different architectural and interior design firms established different parts of Pakistan, and somehow that Pakistanis attitude and mindset have generally for the most part been influenced by British colonial past and European style. European and British influence has modified the approach that Pakistani individuals glance at themselves and in some aspects loose of a confidence that comes naturally from ancient and majestic civilization. Although, people wants variety with Perfect Blend of Old and new or mix and match with traditional designing décor style. Therefore, advancement in new housing society, improving lifestyle and gaining new knowledge, and use of technology, wants to acquire more than one style approach which portrays the finest living in developed housing society because of safety and security and leading comfortable life with all facilities. The better designs of Pakistani houses have capacity to develop better interior decoration space which look unique and may become a symbol of status. Figure 9

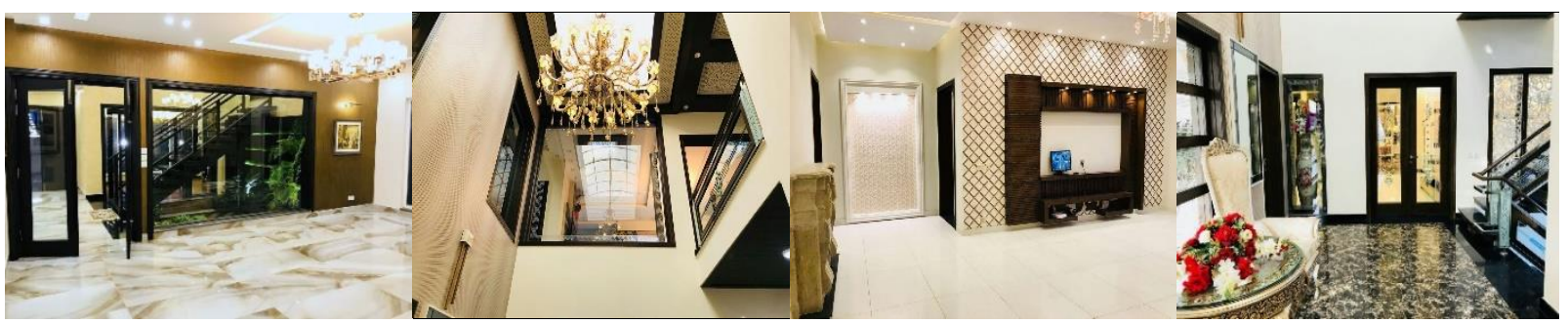

Figure 9. interiors of developed housing societies use of marble,wall paper and wood work

The traditional decorative cultural touch given to the modern houses are the purest form of feelings in contemporary 
living. Pakistanis are always interested in decoration and modifications to their home interiors and so are always searching for useful ideas and solutions in implementation of aesthetic values and design concepts while grabbing new trend. The internal building decor is a combination of space and that space is utilized by decorating with paintings (use a mural art), use of wall papers or texture on wall and other works on accent wall to enhance the beauty of the interior and contribute towards artistic atmosphere. For this purpose they emphasizing on a style in which they can showcase their wealth. Figure 10

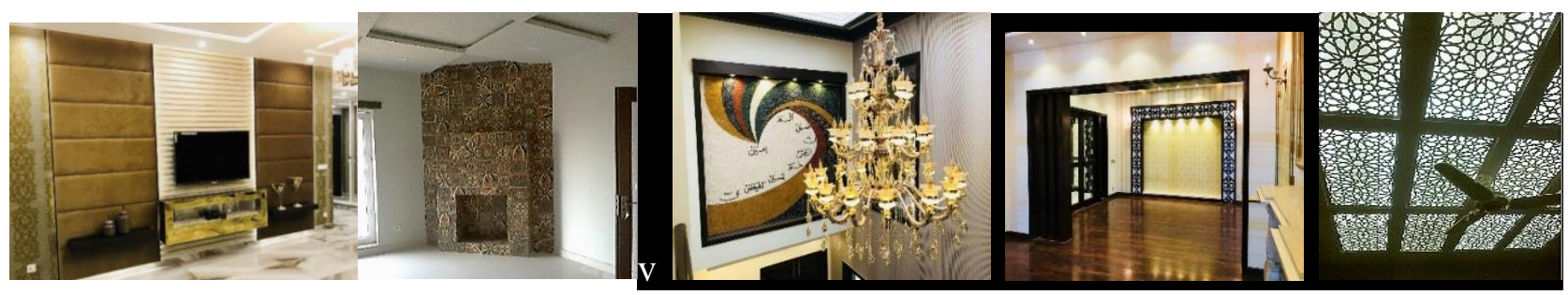

Figure 10. mural mosaic art on wall with Islamic scripts and wood screen work with Islamic geometrical floral patterns on wall and ceiling

Pakistani interior decoration in homes built in developed housing societies particularly related to space the designs are made keeping in view the space aspect it focuses on being dynamic and static, virtual and real space relationships. The space is considered an important aspect of design because it provides an opportunity to the people for being united. At the same time the space used in Pakistani houses in such a manner that having some divisions to make separation for the drawing room where guest can be entertain with respect and honor.

Study shows that Pakistani culture has the capacity to adopt multi-cultural values and décor practices in the society. Values of any country can be judged by the people of that particular country by aesthetics used in the culture. Although it is found that no stick yard is available for examining the concreteness of the aesthetic sense among people and cultures but the good looking interior looks good to all. The two major elements include human society with in the Islamic values and natural harmony that is necessary to contribute towards artistic beauty is considered as the opinion leaders or influencer in design field. But the major complications rising in Pakistani society that is sense of showcasing wealth is imposed on the people in modern living that is not actually considered right. People who are judging the artistic beauty is considered as experts that is not actually desired and at the same time the display of money and power are introduced to the people. This is not really considered the art or the aesthetics by the people who look beauty as beauty. Pakistan historical cultural heritage remained a great fortune by being a source for the innovation and development of design. The composition of interior design and decorative art makes culture. In simple words the interpretation of the ideologies and its implication, in fact, is cultural design. Looking upon the mentioned thoughts this study which supplements each other and contributing to the cultural beauty in Pakistan. But Problem is rising in using inappropriate imported decorative products. Pakistan has rich resources and also does not lack of skilled artisans when it comes to quality of decorative handicraft. However, there is a need to utilize these rich resources in order to flourish the decorative art and craft industry of Pakistan. Collectively needs to be compelled to constantly improve their cultural vogue, to strengthen the standard of living. Pakistani society searching for a source of style innovation combine with cultural living.

\section{Conclusions}

With the gradual improvement of the living environment, people are pursuing more satisfaction and spiritual meaning; therefore, the traditional fundamental of Pakistan are formed in modern living, and brings Pakistan to the traditional cultural attraction in modern living which actual needs of the people. Pakistan's interiors and decorative styles are not limited to one style; they prefer to adopt what they feel good in some specific decorating and interior design styles. Thus, they blend those decorative elements into their homes. Many Pakistani people like eclectic décor style may be they are eclectic themselves, not fitting in one style or stereotype. They choose what they like, in interior decor wise, and they don't feel afraid or afraid to put it all out in interior space .despite of it goes against any popular styles of interior decorating, such as contemporary, transitional or eclectic style. Presently in Pakistan it is at the stage of transitions. People are not adjusting them in one style, in their efforts to make their homes attractive they have made a blend of the two having an appropriate contemporary style but somewhere failed to achieve good results use inappropriate blending. At the same time, designers can use their perceptions and efforts to create "new Pakistani-style ornate art", which enriches Pakistan's traditional culture around the world. Excessive decorative elements and excessive use of imported decorative items, cause lacking Pakistan's unique cultural atmosphere or flavor. Study shows Pakistani Décor style is not rigid; it is close to nature, bright colors and printed fabrics, various design patterns and natural materials, so Pakistani interior designers and decorators should consider using traditional designs and materials with modern essence, especially in the launched new housing society, making its interior design more attractive 
The traditional culture of Pakistan is rich enough to provide soothing effects in the interior design and must be used as a first priority.

\section{References}

Castells, M. (2010). The Power of Identity: The Information Age: Economy, Society, and Culture. Volume II. A Johan Wiley \& Sons, Ltd.

Chan, C. S. (2000). "Can style be measured?" Design Studies, 21(3), 277-291. https://doi.org/10.1016/S0142-694X(99)00011-3

Chen, K., \& Owen, C. L. (1997). Form language and style description. Design Studies, 18, 249-274. https://doi.org/10.1016/S0142-694X(97)00002-1

Common wealth, Pakistan history http://thecommonwealth.org/our-member-countries/pakistan/history

Dales, G. F. (1964). "The mythical massacre at Mohenjo-daro." Expedition, 6(3), 36.

David, W. (2006). The Evolution of Style https://patterninislamicart.com/background-notes/the-evolution-of-style

Hall, E. (1959). The Silent Language. New York, Doubleday and Co, Inc.

Italian Baroque interior design, https://en.wikipedia.org/wiki/Italian_Baroque_interior_design

Knight, T. W. (1986). Transformation of the meander motif on Greek Geometric pottery. Design Computing, 1, 29-67.

Kroeber, A. L., \& Kluckhohn, C. (1952). Culture: A Critical Review of Concepts and Definitions. Papers of the Penbody Museum of American Archaecology and Ethnology, 47/1 Cambridge Mass: Harvard University.

Matsumoto, D. (1996). Culture and Psychology. Pacific Grove, C.A. Brooks/Cole

Naqvi 1973 conference

http://thecommonwealth.org/our-member-countries/pakistan/history

https://www.harappa.com/blog/mohenjodaro-Pakistanhistory

https://www.invaluable.com/blog/british-furniture-guide/

https://www.invaluable.com/decorative-art/pc-HV9SJ0PETO/

Naqvi, A. (2010), Image and identity: Fifty years of painting and sculpture in Pakistan, Oxford university press, Second edition, ISBN 978-0-19-547172-4 p. 232-259 Rao, Shikaripur Ranganatha. 1973. Lothal and the Indus civilization: New York: Asia Publishing House.

Wright, R. P. (2010). The ancient Indus: urbanism, economy, and society: Cambridge University Press.

Zegarac, V. (2007). A cognitive pragmatic perspective on communication and culture. In Kotthoff, H \& Spencer-Oatey (Eds). Book of Intercultural Communication. Berlin: Walter de Grayter pp. 31-53.

\section{Copyrights}

Copyright for this article is retained by the author(s), with first publication rights granted to the journal.

This is an open-access article distributed under the terms and conditions of the Creative Commons Attribution license which permits unrestricted use, distribution, and reproduction in any medium, provided the original work is properly cited. 